\title{
CHANGES IN THE CREDIT RISK PROFILE OF POLISH LOCAL GOVERNMENTS. AN ASSESSMENT OF UNSYSTEMATIC RISK
}

The paper presents research devoted to changes in the local government credit risk profile in Poland. Firstly, the risk assessment is conducted based on the free operating cash flow and net debt approach as a preferred alternative to the statutory debt limits. Then, using the Data Envelopment Analysis method, an analysis is conducted of changes of unsystematic risk of local government subcategories during the period of economic slowdown. The study finds that the general risk profile of local governments strongly deteriorated compared to the precrisis year of 2008. Since 2011 it has slightly improved. However, this partial improvement was mainly due to a drop in market interest rates in 2013. Adjusting data for this factor reveals that the financial standing would not have changed in a positive way. Two local government subcategories have relatively inferior risk profiles. The first one is the towns with county rights, which represent more than one third of the population and revenues of the local government sector. They have the highest debt levels compared to their debt service capacities, and some of them accumulated high unsystematic risk. Approximately $20 \%$ of them have debt service indicators below safe levels. The second category is the counties. Despite relatively low debt levels, there is high systematic risk in this group. Without system reform of the counties, approximately $25 \%$ of them may have problems with performing their statutory tasks or servicing their debt in the medium term. The rural boroughs are the safest local government category in Poland.

Keywords: local government debt, local government risk, unsystematic risk, DEA method

DOI: $10.15611 /$ aoe.2017.2.07

\section{THEORETICAL BACKGROUND}

The financial and economic crisis, which originated in 2007 in the United States, had a profound impact on the finances of local governments (LGs) across the European Union. Their debt/GDP ratio grew significantly from an average of $5 \%$ in 2007 to $7 \%$ in 2012 . The impact varied markedly among countries, e.g. in Spain this ratio grew in 2007-2012 from 8.6\% to $22.1 \%$, in Belgium from $8.7 \%$ to $11.9 \%$, and on the other hand, in Bulgaria and Croatia

\footnotetext{
${ }^{*}$ Quantitative Economics Department, Warsaw School of Economics.
} 
it remained around $1 \%$ of GDP. In many countries the crisis also caused limitations in the financial resources transferred to local governments. That influenced in a negative way the financial standing of local governments and their ability to provide public services as described in (Vammalle, Hulbert 2013).

The financial soundness of the LG sector may be an important factor facilitating economic growth. Several studies deliver evidence of the high effectiveness of LG spending and that fiscal decentralization increases GDP per capita, productivity, human capital as well as the share of public funds directed to capital expenditure. Numerous analyses were conducted especially by OECD departments. The results, as well as a broad review of other research, are presented in (Blöchliger 2013), (Blöchliger, Égert 2013) and (Fredriksen 2013). However there is also evidence of politically driven transfers to local governments, targeted at securing support for elections, which causes inefficiencies, see (Veiga, Veiga 2013) and (Haan de, Klomp 2013).

The debate on how to implement fiscal consolidation and what choice of instruments should favour long-term growth is ongoing. The impact of fiscal policy tightening on growth is analyzed in (Barrell et al. 2012). It shows the possible adverse impact of fiscal consolidation on growth in the short-term horizon. As described in (Sutherland et al. 2012) the focus should be on finding policies with low multipliers in the short term (e.g. related to pension systems) and undertaking reforms of budgetary institutions. Macroeconomic risks associated with deleveraging, including their impact on consumption, are modelled in (Eggertsson, Krugman 2012). There is also a risk that increased productivity can reduce output in the case of the deleveraging process. As a result, it creates considerable difficulty for decision-makers to choose an optimal policy. In the OECD reports devoted to Denmark (OECD 2012) and Finland (OECD 2014), policy recommendations point to merging LGs into bigger entities and implementing legal rules, which restrict expenditure growth. The flaws of the fiscal austerity model for municipalities as a response to crisis are shown in (Peck 2014) and (Donald et al. 2014).

The economic slowdown also had an impact on the Polish LG sector, which recorded rapid growth of indebtedness. The LGs' debt to GDP ratio grew from $2.3 \%$ in 2008 to $4.2 \%$ in 2013 . This was a result of systematic factors such as a slowdown of revenue growth combined with an increased amount of performed commissioned tasks as well as the individual policies of each entity in both cost management and the implementation of 
environmental and infrastructural projects. This situation was accompanied by changes of legislation regarding debt limits for LGs. As shown in (Marchewka-Bartkowiak, Wiśniewski 2012) and (Kluka, Kluza 2012) these changes restricted the financial capacity of several Polish LGs and forced some soft restructuring of their debt - mainly by refinancing existing debt with longer tenors and grace periods for capital repayments. That situation also caused an increase in interest margins for new LG debt (Kluza 2013). There is still an ongoing economic and political debate on how appropriate debt limits for LGs should be designed (Czudec, Kata 2012), and what revenue level is relevant for LGs taking into consideration the tasks they are commissioned to perform. The gap in revenues of Polish LGs is estimated at between $0.6 \%$ and $1.0 \%$ of GDP (ZMP 2012), (Kluza 2014).

The above phenomena are associated with the growing risk of the LG sector as well as of individual LGs. Since this growth is associated with increased indebtedness, the adjustment process may lead to more deleveraging and have a bigger adverse impact on the real economy than the adjustment of non-leveraged distortions of the economy (Brunnermeier, Oehmke 2012), e.g. compare the impact of the bursting of the financial bubble with the technology bubble. Since this research is focused on unsystematic credit risk, the risk measures it uses are based on (Palepu et al. 2004, ch. 9 and 14) and (Crouhy, Galai 2000, ch. 7) and in Polish literature on (Jajuga 2009), where they are described extensively. Literature on systemic market risk is reviewed in (Bisias et al. 2012). For a critical assessment of the accuracy of credit rating agencies, both in terms of unsystematic and systematic risk, see for example (Hilscher, Wilson 2013) and (Abad, Robles 2012).

The research literature refers mainly to the risk assessment of private sector entities and financial institutions. There is remarkably less literature devoted to risk measurement of public sector entities, which is understandable taking into account the considerably lower and often even negligible risk of this sector. The basic approach to measure and manage LG credit risk is presented in (Peterson 1998). Specific methodologies for the public sector are derived by credit rating agencies. The sector-specific risk assessment criteria may be found in (FITCH 2012), (FITCH 2014), (S\&P 2013), (S\&P 2014b). Examples of the assessment of individual local governments in Poland are in (S\&P 2014a) and (FITCH 2013).

In this work, the author presents research devoted to changes in the local government credit risk profile during the economic slowdown. The aim of the research is to evaluate whether Polish LGs are exposed to an increasing 
credit risk. The analysis consists of two parts. The first one compares the official risk measures (statutory limits) for LGs in the 2008-2013 period with risk assessment based on financial analysis practice. Next, unsystematic risk changes of LGs during the recent crisis are assessed using the Data Envelopment Analysis method (DEA). The DEA method was put forward by (Charnes et al. 1978) and developed for specific implementations - see for example (Cooper et al. 2011) or (Kucharski 2011). The recent examples of the application of the DEA method in the assessment of the efficiency of Polish LGs in the provision of public services and conducting public investments are in (Łękawa 2012) and (Zioło 2012).

Using financial indicators and the DEA results, subcategories of LGs are identified where the unsystematic and systematic risk increased the most. The analysis provides guidance on which local government categories are more vulnerable to problems with servicing their financial liabilities in the future due to their cost management and investment policies, and which ones are undergoing structural problems.

\section{METHODOLOGICAL NOTES}

The analysis encompasses all local governments in Poland with only one exception: the town and the county of Wałbrzych were excluded due to their reorganization in 2012. A part of Wałbrzych county was merged with the municipal borough, and a new entity - Wałbrzych town with county rights was created. The debt of the county was entirely transferred to the town, thus distorting the historical comparisons.

Note that the debt of LGs does not include the liabilities of public health care entities owned by local governments, which amounted to PLN 3.9 billion at the end of 2013 as well as the liabilities of cultural entities and similar units (PLN 0.5 billion of debt). They are owned mainly by counties, towns with county rights and provinces. These liabilities are usually undue and serviced directly by these entities. Including fully these contingent liabilities in the LG debt would raise the debt/revenue ratio in 2013 from $37.7 \%$ to $40.1 \%$ (without increasing the denominator by the revenues of these entities). The debt ratios also do not include the debt of utilities and other municipal companies. This is correct as these are separate legal entities without implicit LG guarantees and typically with strong operational cash flow, and do not require capital injections from LGs.

Also note that the risk analyzed in this paper is credit risk and the refinancing risk associated with it. 
All data regarding local governments used in this research comes from the BESTI@ system run by the Ministry of Finance of Poland. Data about the population is from the Central Statistical Office (GUS). Calculations for the DEA method were carried out with Microsoft Excel (small data sets) and Efficiency Measurement System ver. 1.3.0 software (all data sets). Control calculations for the same data sets with different programs delivered exactly the same results.

\section{FINANCIAL STANDING OF LOCAL GOVERNMENTS IN POLAND - STATUTORY LIMITS PERSPECTIVE}

In Poland there are 2,809 local government (LG) entities. They form a three tier system which consists of boroughs (in Polish: gminy), counties (Polish: powiaty) and provinces (Polish: województwa). The largest towns (66 entities at the end of 2013) perform both the functions of boroughs and counties, and they form a separate category called 'towns with county rights' (TWCR). Boroughs (gminy) consist of three categories: municipal boroughs (MB), municipal-rural boroughs (MRB) and rural boroughs (RB).

In their financial policies, LGs in Poland have to comply with several statutory limits and related regulations implemented by the Public Finance Law (PFL), and they are also controlled by the Regional Comptroller Offices (RIOs). For each new financing, the LG has to obtain a positive formal recommendation from the RIO. At the end of each quarter, LGs are obliged to prepare comprehensive financial statements, e.g. RbNDS (with revenues, expenditures and financing flows), $\mathrm{RbN}$ (receivables), $\mathrm{RbZ}$ (liabilities), $\mathrm{Rb} 27 \mathrm{~S}$ (detailed revenues), $\mathrm{Rb} 28 \mathrm{~S}$ (detailed expenditures), etc. In this paper, the author also presents notation from these financial statements allowing exact reference.

In Poland the debt and interest payments which are related to projects cofinanced with EU funds are excluded from all statutory limits. Until 2014, there were two statutory limits (plus some auxiliary rules for situations when general government debt exceeds precautionary thresholds from the PFL). The first one sets the maximum debt level for each LG at $60 \%$ of its current year total annual revenues $(\mathrm{D} / \mathrm{R}$ ratio):

$$
\frac{\text { Debt }}{\text { Revenues }}=\frac{(R b Z, E-R b Z, C 1)}{R b N D S, A} \leq 60
$$

where $R b Z, C 1-$ sum of debt related to EU projects. 
The second ratio limited the financial outflows for each $\mathrm{LG}$ to a maximum $15 \%$ of its current year total annual revenues (FO/R ratio).

$$
\frac{\text { Financial outflows }}{\text { Revenues }} \leq 15 \%
$$

where:

Financial outflows $(F O)=R b N D S, D 21 \_D 23 \_D 24-R b N D S, D 211 \_D 231 \_D 241$ + Rb28S,par.801_802_806_807_808_809_811_812_813_814- $\bar{R} b 28 S, X$, of which $R b 28 S, \bar{X}$ - interest paid on debt related to EU projects, calculated as a sum of paragraphs in $R b-28 S: 8011-8012,8015-8019,8021-8022,8025-$ $8029,8061-8062,8065-8069,8071-8072,8075-8079$, 8081-8082, 8085$8089,8091-8092,8095-8099,8111-8112,8115-8119,8121-8122,8125-$ $8129,8131-8132,8135-8139,8141-8142,8145-8149$.

Revenues $(R)=\operatorname{RbNDS}, A$

In 2014 the above limits were replaced by the individual debt limit from par. 243 of the Public Finance Law. It states that for an $n$th year the relationship of financial outflows to total revenues (left hand side of equation, LHS) cannot exceed the average relationship for the previous three years of current revenues plus sales of assets minus current expenses to total revenues (right hand side of equation, RHS). In the PFL this is defined as:

$$
\left(\frac{F O}{R}\right)_{n} \leq \frac{1}{3} *\left(\frac{D b_{n-1}+S m_{n-1}-W b_{n-1}}{R_{n-1}}+\frac{D b_{n-2}+S m_{n-2}-W b_{n-2}}{R_{n-2}}+\frac{D b_{n-3}+S m_{n-3}-W b_{n-3}}{R_{n-3}}\right)
$$

where:

$F O$ and $R$ are defined as in the $\mathrm{FO} / \mathrm{R}$ ratio.

$D b$ - current revenues $(R b N D S, A 1)$

$S m$ - gross revenues from sales of assets (Rb27S,par.077_078_087)

$W b$ - current expenditures (RbNDS, B1).

Since 2011 there has also been a requirement for LGs to have an operational surplus, calculated as operating revenues plus unused cash and cash equivalents from the previous year minus operating expenses. The definition of this rule is provided in par. 242 of the PFL.

The new statutory limit on LG financing (par. 243) is more restrictive than the previous limits. The new 2014 regulation is more liberal than the previous $15 \%$ limit only for $135 \mathrm{LGs}$, i.e. less than $5 \%$ of all LGs (KRRIO 2013 , p. 211). For the remaining $95 \%$ it will be more restrictive. On the other hand, the new statutory limit will allow some LGs, mainly larger towns, to increase their indebtedness to over $60 \%$ of the $\mathrm{D} / \mathrm{R}$ ceiling. 
Table 1

Financial ratios for local government sector from the Public Finance Law

\begin{tabular}{|c|c|c|c|c|c|c|}
\hline & 2008 & 2009 & 2010 & 2011 & 2012 & 2013 \\
\hline Number of LGs & 2808 & 2808 & 2809 & 2809 & 2809 & 2809 \\
\hline $\mathrm{D} / \mathrm{R}$ ratio & $20.2 \%$ & $26.0 \%$ & $33.8 \%$ & $38.4 \%$ & $38.2 \%$ & $37.7 \%$ \\
\hline $\begin{array}{l}\mathrm{D} / \mathrm{R} \text { excl. debt for EU projects (as } \\
\text { defined in the PFL) }\end{array}$ & $18.7 \%$ & $24.8 \%$ & $30.8 \%$ & $34.3 \%$ & $34.6 \%$ & $32.1 \%$ \\
\hline LGs with $\mathrm{D} / \mathrm{R}$ ratio above $60 \%$ & 3 & 17 & 70 & 135 & 95 & 89 \\
\hline $\begin{array}{l}\text { LGs with D/R ratio excl. debt for EU } \\
\text { projects above } 60 \% \text { (statutory limit) }\end{array}$ & 1 & 6 & 17 & 32 & 30 & 37 \\
\hline FO/R ratio & $5.5 \%$ & $4.9 \%$ & $5.6 \%$ & $7.2 \%$ & $7.7 \%$ & $8.0 \%$ \\
\hline LGs with FO/R ratio above $15 \% *$ & 46 & 21 & 48 & 220 & 331 & 326 \\
\hline $\begin{array}{l}\text { par. } 243 \text { rule: relation of RHS to LHS; } \\
\text { median value }\end{array}$ & - & - & $249 \%$ & $140 \%$ & $98 \%$ & $101 \%$ \\
\hline $\begin{array}{l}\text { LGs with the above relation below the } \\
\text { required } 100 \% *\end{array}$ & - & - & 482 & 1017 & 1441 & 1391 \\
\hline
\end{tabular}

* without excluding debt and interest payments associated with EU projects, which would be an exact calculation of the statutory limit

Source: Ministry of Finance, (KRRIO 2012, 2013), own calculations.

From the perspective of statutory limits, the financial situation of LGs in 2012 and 2013 could be perceived as relatively unfavourable, taking into consideration how many entities did not comply with the statutory requirements. Although the debt growth slowed down, the number of LGs not fulfilling the $60 \%$ limit (excluding debt for EU projects) grew to 37 entities in 2013. The financial outflows indicator also reached its historical maximum of $8 \%$ and 326 entities exceeded the $15 \%$ ceiling for this ratio. Similarly, for the last two years the RHS of par. 243 is very low. As a result, around half of the LGs would not have satisfied this limit, which indicates the strong deterioration of their operating surpluses relative to debt service payments.

However this negative picture is partly misleading. The high ratio of financial outflows to revenues is largely a result of the refinancing of historical debt with new debt. ${ }^{1}$ Additionally, the new limit from par. 243 in

\footnotetext{
${ }^{1}$ In 2013 there was no clear position of the RIOs on how to include refinancing of debt in the FO/R ratio. Typically it was included but in some situations the RIOs accepted the exclusion of refinanced debt from this ratio, see e.g. the statement GP-WR-073-26/13 from the RIO in Wrocław dated 19 November 2013, the resolution 8/2013 of RIO in Kielce dated 21 January 2013, and the resolution 5/K/2013 of RIO in Bydgoszcz dated 22 January 2013.
} 
the PFL was not obligatory in 2013, so with a high probability a lot of LGs downscaled it in 2012-2013 in order to increase the financial cushion for 2014.

Thus, to evaluate more precisely the current financial standing of Polish LGs, a more detailed analysis is required. Specifically it should involve replacing the statutory limits from the PFL with more relevant risk analysis indicators as well as breaking down the analysis into specific subcategories of LGs.

\section{ALTERNATIVE ASSESSMENT OF THE FINANCIAL STANDING OF POLISH LOCAL GOVERNMENTS}

The limits on LG financing from the Public Finance Law were undoubtedly very important in preventing Polish LGs from over-borrowing. However, their usefulness in assessing the financial standing of LGs is limited. For example, they exclude the debt collected for co-financing EU projects from statutory limits. From a political perspective this is plausible since such a regulation helps to absorb EU funds. However, from a risk assessment perspective this is not correct as this debt includes the financing of LGs' own contributions in projects, which must be repaid. In addition, it covers bridge financing, which not only involves the necessity of bearing interest payments, but also carries the risk of returning the EU aid (see, e.g. the case of the Kosakowo airport project in Gdynia).

Moreover the ' $60 \%$ ' statutory limit takes into account gross debt instead of net debt. Furthermore the $15 \%$ ratio and par. 243 rule are inflated by refinancing activities as they also include a rollover of debt. Thus, even such reasonable activity as substituting more expensive debt with cheaper debt can be prohibited when this operation results in exceeding the statutory limits. Thirdly, the new par. 243 rule which refers itself as being based on operating surplus, is in fact loosely connected to such an approach. On the RHS, the 'operating surplus' in a numerator is diminished by financial expenses and increased by sales of assets. Additionally, the denominator for the RHS and LHS includes current revenues, sales of assets as well as project subsidies. That makes this debt indicator a partial function of investment policy instead of operating free cash flow.

The above flaws prompt to design alternative, more relevant indicators for assessing LGs financial standing. Traditional literature on corporate finance and financial analysis delivers several useful indicators, see e.g. 
(Palepu et al. 2004 ch. 9 and 14) and (Crouhy, Galai 2000, ch. 7). ${ }^{2}$ Based on them and the author's own experience in the financial sector (more than 15 years in financing public and private sector entities), the following indicators are proposed. The first one is used only as a descriptive indicator. The next two ratios are used also in assessing the unsystematic risk.

a. Net debt / Revenues (ND/R ratio)

$$
\frac{\text { Net Debt }}{\text { Revenues }}=\frac{R b Z, E-(R b N, N 1+R b N, N 3)}{R b N D S, A}
$$

Debt is net of cash and cash equivalents, but not receivables (mainly tax receivables). In the denominator, there are total revenues (like in the $\mathrm{D} / \mathrm{R}$ ratio). This is more appropriate than taking current (operating) revenues since other revenues usually contain subsidies directly linked to investments for which the debt is acquired. The debt related to EU funds is not excluded.

b. EBIT / Gross Interest or EBITDA / Gross Interest (EBITDA/GI ratio)

EBITDA is defined as:

RbNDS,A1 - RbNDS,B1 + Rb28S,par.801_806_807_808_809_811_812_813_814

Gross Interest $(G I)$ is defined as:

Rb28S,par.801_806_807_808_809_811_812_813_814

Note that in the case of LGs, EBIT (Earnings before Interest and Taxes) is equal to EBITDA (Earnings before Interest, Taxes, Depreciation and Amortization) since LG reporting in Poland is based on a cash basis. Thus in this paper this indicator will be called EBITDA / Gross Interest.

The negative warning sign is generated if this indicator is below the value of 2.0 for a given entity.

c. FOCF / Net Debt (FOCF/ND ratio)

FOCF is defined as:

RbNDS,A1-RbNDS,B1+Rb28S,par.801_806_807_808_809_811_812_813_814

Net Debt $(N D)$ is defined as:

$R b Z, E-(R b N, N 1+R b N, N 3)$

In this indicator, debt should include only interest bearing liabilities. In the case of Polish LGs there is no need to make adjustments, since approximately $99 \%$ of their liabilities are due to the financial sector. FOCF (Free Operating Cash Flow' is an equivalent of an operating surplus from statutory limits, but is more correct as it does not include the sale of assets and the interest paid. The typical indicator form would be Net Debt / FOCF.

\footnotetext{
${ }^{2}$ See also (Hilscher, Wilson 2013) for research showing that models based on simple financial indicators like leverage, profitability, etc. may have better accuracy of default forecasting than complex ratings in the case of unsystematic risk in the corporate sector.
} 
However, for the DEA method it is required to use an inversed form in order to keep 'the higher the better' logic. For sound entities this indicator should amount to at least $20 \%$.

Indicators based on total debt service (encompassing both principal and interest payments), e.g. debt service to recurring revenues as proposed by (Peterson 1998), are not analyzed for two basic reasons. Firstly, such indicators are strongly distorted by the refinancing of loans and bonds, which started in 2011. Secondly, unlike the corporate sector, the refinancing risk for LGs proved to be very low in Poland, thus the critical issue is to check the amount of space available for a given LG to service the interest payments. Also, contrary to statutory limits, there is no elimination of debt and interest payments related to EU funds from the ratios.

Table 2

Alternative financial ratios for the local government sector

\begin{tabular}{l|c|c|c|c|c|c}
\hline \multicolumn{1}{c|}{ in \% } & $\mathbf{2 0 0 8}$ & $\mathbf{2 0 0 9}$ & $\mathbf{2 0 1 0}$ & $\mathbf{2 0 1 1}$ & $\mathbf{2 0 1 2}$ & $\mathbf{2 0 1 3}$ \\
\hline ND/R ratio & 7.7 & 15.4 & 24.7 & 29.3 & 29.6 & 30.3 \\
\hline EBITDA/GI & 1376 & 911 & 579 & 494 & 427 & 596 \\
\hline $\begin{array}{l}\text { \% of LGs with EBITDA/GI above } \\
2.0\end{array}$ & 95 & 90 & 78 & 84 & 88 & 95 \\
\hline FOCF/ND & 175 & 56 & 28 & 27 & 29 & 31 \\
\hline
\end{tabular}

Source: own calculations.

The indicators in Table 2 show that the worst financial situation of Polish LGs was in the 2011-2013 period. Although in 2013 there was some improvement of indicators based on operational surpluses, the free resources of LGs are systematically reduced as the net debt grows, and in 2013 for the first time it exceeded $30 \%$ of their revenues.

The results for 2010 provide a sort of surprise - despite the relatively low debt and high EBITDA, only $78 \%$ of LGs had a safe level of EBITDA/Gross Interest ratio (see also Table 3). To solve this puzzle, one has to remember that up to 2010 there was no requirement of operational surplus defined in art. 242 of the PFL. Thus the data between 2010 and following years is to some extent incomparable, since low or negative EBITDA in some LGs could have been the result of an intentional policy and not the result of difficulties with fulfilling statutory obligations.

A constructive assessment of LG financial conditions requires the analysis of separate LG subcategories. The differentiation between subcategories is very large and is related to both revenues as well as expenditures. For example, 
boroughs have a substantial tax base, i.e. PIT, CIT, local taxes (property tax, agriculture tax) compared to counties. In 2013, taxes and related revenues in boroughs amounted to PLN 28.1 billion out of PLN 73.6 billion of current revenues (38\%), in TWCR excluding Warsaw PLN 19.9 billion out of PLN 45.6 billion (44\%) and in counties only PLN 3.7 billion out of PLN 21.3 billion (17\%). Similarly, each LG category performs a different set of public tasks, especially in the fields of education, health care, transport services, road and railway infrastructure as well as water and sewage services. As a result, a debt level which is safe for a municipal borough might be dangerously high for a county. Selected indicators for LG subcategories are presented in Table 3.

Table 3

Standard and alternative financial ratios; breakdown by local government subcategories; all data in $\%$

\begin{tabular}{|c|c|c|c|c|c|c|}
\hline TWCR (65 entities) & 2008 & 2009 & 2010 & 2011 & 2012 & 2013 \\
\hline $\mathrm{D} / \mathrm{R}$ ratio & 25.8 & 37.2 & 43.5 & 49.4 & 48.3 & 48.0 \\
\hline $\mathrm{FO} / \mathrm{R}$ & 5.8 & 5.2 & 6.5 & 8.0 & 7.7 & 8.0 \\
\hline par. 243 rule: ratio of RHS to LHS; median value & & & 207.4 & 120.4 & 92.8 & 90.5 \\
\hline Net debt/Total revenues & 14.3 & 25.5 & 33.9 & 38.4 & 39.4 & 40.2 \\
\hline EBITDA/Gross Interest & 1039 & 561 & 400 & 342 & 273 & 433 \\
\hline$\%$ of LGs with EBITDA/GI above 2.0 & 97 & 85 & 71 & 78 & 75 & 83 \\
\hline FOCF/Net Debt & 90 & 28 & 18 & 18 & 17 & 21 \\
\hline$\%$ of LGs with FOCF/Net Debt above $20 \%$ & 95 & 65 & 37 & 38 & 45 & 43 \\
\hline MB (240 entities) & 2008 & 2009 & 2010 & 2011 & 2012 & 2013 \\
\hline $\mathrm{D} / \mathrm{R}$ ratio & 19.4 & 26.4 & 32.9 & 36.0 & 35.7 & 34.2 \\
\hline $\mathrm{FO} / \mathrm{R}$ & 5.6 & 5.4 & 5.9 & 6.9 & 7.6 & 8.3 \\
\hline par. 243 rule: ratio of RHS to LHS; median value & & & 237.6 & 152.7 & 99.6 & 102.4 \\
\hline Net debt/Total revenues & 6.1 & 17.0 & 24.7 & 28.6 & 28.5 & 27.8 \\
\hline EBITDA/Gross Interest & 1410 & 715 & 440 & 446 & 395 & 557 \\
\hline$\%$ of LGs with EBITDA/GI above 2.0 & 92 & 77 & 65 & 78 & 76 & 90 \\
\hline FOCF/Net Debt & 215 & 42 & 21 & 25 & 27 & 30 \\
\hline$\%$ of LGs with FOCF/Net Debt above $20 \%$ & 92 & 69 & 47 & 56 & 58 & 69 \\
\hline MRB (602 entities) & 2008 & 2009 & 2010 & 2011 & 2012 & 2013 \\
\hline $\mathrm{D} / \mathrm{R}$ ratio & 19.2 & 25.2 & 33.2 & 37.4 & 36.4 & 35.4 \\
\hline $\mathrm{FO} / \mathrm{R}$ & 5.3 & 5.1 & 6.0 & 7.8 & 8.9 & 9.2 \\
\hline par. 243 rule: ratio of RHS to LHS; median value & & & 217.5 & 132.3 & 90.8 & 90.0 \\
\hline Net debt/Total revenues & 8.2 & 15.9 & 25.7 & 30.7 & 29.5 & 29.3 \\
\hline
\end{tabular}




\begin{tabular}{|c|c|c|c|c|c|c|}
\hline EBITDA/Gross Interest & 1433 & 1072 & 586 & 505 & 470 & 650 \\
\hline$\%$ of LGs with EBITDA/GI above 2.0 & 96 & 90 & 72 & 80 & 87 & 95 \\
\hline FOCF/Net Debt & 154 & 60 & 25 & 27 & 32 & 34 \\
\hline$\%$ of LGs with FOCF/Net Debt above $20 \%$ & 92 & 81 & 52 & 56 & 66 & 74 \\
\hline RB (1571 entities) & 2008 & 2009 & 2010 & 2011 & 2012 & 2013 \\
\hline $\mathrm{D} / \mathrm{R}$ ratio & 14.5 & 18.3 & 26.6 & 30.8 & 29.5 & 28.7 \\
\hline $\mathrm{FO} / \mathrm{R}$ & 4.4 & 4.2 & 5.0 & 7.8 & 8.9 & 8.7 \\
\hline par. 243 rule: ratio of RHS to LHS; median value & & & 292.9 & 143.3 & 100.8 & 106.4 \\
\hline Net debt/Total revenues & 1.3 & 6.8 & 17.5 & 22.2 & 20.5 & 20.3 \\
\hline EBITDA/Gross Interest & 2406 & 2072 & 1208 & 784 & 720 & 1005 \\
\hline$\%$ of LGs with EBITDA/GI above 2.0 & 97 & 94 & 83 & 86 & 92 & 98 \\
\hline FOCF/Net Debt & 1158 & 188 & 54 & 44 & 54 & 59 \\
\hline$\%$ of LGs with FOCF/Net Debt above $20 \%$ & 95 & 89 & 68 & 68 & 79 & 85 \\
\hline Counties (313 entities) & 2008 & 2009 & 2010 & 2011 & 2012 & 2013 \\
\hline $\mathrm{D} / \mathrm{R}$ ratio & 15.8 & 19.4 & 24.1 & 26.0 & 26.5 & 25.5 \\
\hline $\mathrm{FO} / \mathrm{R}$ & 4.6 & 4.1 & 4.9 & 5.4 & 6.6 & 7.3 \\
\hline par. 243 rule: ratio of RHS to LHS; median value & & & 152.4 & 106.5 & 88.3 & 93.6 \\
\hline Net debt/Total revenues & 4.5 & 9.2 & 14.9 & 17.2 & 16.7 & 18.8 \\
\hline EBITDA/Gross Interest & 669 & 576 & 433 & 523 & 408 & 571 \\
\hline$\%$ of LGs with EBITDA/GI above 2.0 & 85 & 79 & 73 & 88 & 81 & 91 \\
\hline FOCF/Net Debt & 158 & 58 & 30 & 39 & 38 & 35 \\
\hline$\%$ of LGs with FOCF/Net Debt above $20 \%$ & 87 & 77 & 62 & 75 & 72 & 74 \\
\hline Provinces (16 entities) & 2008 & 2009 & 2010 & 2011 & 2012 & 2013 \\
\hline $\mathrm{D} / \mathrm{R}$ ratio & 18.1 & 15.6 & 30.4 & 36.9 & 40.1 & 41.1 \\
\hline $\mathrm{FO} / \mathrm{R}$ & 7.9 & 5.4 & 3.2 & 5.1 & 4.3 & 5.3 \\
\hline par. 243 rule: ratio of RHS to LHS; median value & & & 809.0 & 508.8 & 255.9 & 259.9 \\
\hline Net debt/Total revenues & -0.4 & 6.0 & 18.2 & 27.1 & 29.9 & 33.1 \\
\hline EBITDA/Gross Interest & 3277 & 1649 & 944 & 752 & 670 & 720 \\
\hline \% of LGs with EBITDA/GI above 2.0 & 100 & 100 & 100 & 94 & 100 & 100 \\
\hline FOCF/Net Debt & -5576 & 172 & 57 & 43 & 44 & 35 \\
\hline of LGs with FOCF/Net Debt above $20 \%$ & 100 & 100 & 81 & 88 & 100 & 88 \\
\hline
\end{tabular}

Source: own calculations. 
Analysis of data in Table 3 confirms the large differentiation of LG subcategories in terms of both their current financial condition and trends. Notably, the best risk profile is in the rural boroughs which have both relatively low debt and adequately large operating surpluses to service it. There is also a visible improvement of all indicators in this subcategory in 2013 , including a drop of the ND/R ratio below $20 \%$. The second subcategory of LGs with a relatively safe financial situation are the provinces. Like the rural boroughs, they have large operational surpluses compared to debt service levels. However, the provinces systematically increase their indebtedness, and currently have the second highest (after TWCR) ND/R ratio, amounting to $33 \%$. In addition, they are responsible for providing the business continuity of their hospitals and other entities, e.g. regional railways. As a result, the risk profile of this LG category systematically worsens.

The municipal boroughs and municipal-rural boroughs have a moderate financial standing. Their net indebtedness is about $28 \%-29 \%$ and is accompanied by relatively modest operational surpluses. In particular, more than $25 \%$ of these entities have an FOCF lower than $20 \%$ of their net debt, which generates an important warning signal. However, it is worth noting that they managed to visibly improve their risk profile in 2013.

An interesting LG category from the financial perspective is the counties. On the one hand, these entities have a relatively low debt $-\mathrm{ND} / \mathrm{R}$ amounted to $19 \%$ in 2013 . On the other hand, they have low operational surpluses. Such a situation means that servicing even a modest debt becomes a significant burden on their free cash flow. The low operational surpluses of the counties are a systemic problem for this category and there was no improvement in this situation in 2013. Additionally, several counties own hospitals and according to the law are obliged to cover their losses (if they occur), which further weakens the risk profile of this LG category. It is very likely that the counties' current model of functioning, i.e. the modest sources of own revenues and the relatively complex commissioned tasks, will mean that around $25 \%$ of the counties will not be able to sustain their operations and solvency in the medium term. This will force a reform of these entities. Possible solutions might be the merging of weaker counties with stronger ones or with municipal boroughs and the creation of TWCR, changes in their commissioned tasks (e.g. taking over their hospitals by other public entities) or even the elimination of this LG category, i.e. implementing a two-tier local government system.

Last but not least is the category of TWCR. Although there are only 66 TWCR (including Wałbrzych since 2013) out of 2809 LGs, they contain 
$33 \%$ of Poland's population, $36 \%$ of all LG revenues and generate $45 \%$ of LG sector debt. Thus this is a very important subcategory for the LG sector.

Data shows that TWCR have the worst financial standing among LGs from the perspective of debt service capacity. Their ND/R ratio already reached $40 \%$ in 2013 . The average FOCF/ND ratio is dangerously low - for the last four years it has fluctuated around $20 \%$. As a result, more than half of TWCR do not achieve the $20 \%$ threshold regarded as a safe level. Moreover, $17 \%$ of TWCR have an EBITDA/GI ratio below 2.0. The only positive fact is that the above ratios stabilized at current levels in 2013 and there is no further adverse trend.

The financial standing of TWCR, which are the most important LG subcategory, raises a lot of concern. In addition, due to the large size of each TWCR, they also generate large concentration risks for the financial sector.

Summing up, the credit risk of the LG sector was generally the highest in the years 2011-2012. In 2013 it diminished in the municipal boroughs, municipal-rural boroughs and rural boroughs. In the counties and TWCR, it remained at a similar, though relatively high level - it increased only in the case of the provinces.

\section{CHANGES OF UNSYSTEMATIC RISK IN THE LOCAL GOVERNMENT SECTOR}

An important question to answer is whether the adverse changes of risk profile in some LG subcategories are the effect of system changes such as, for example, the relative limitation of their revenues in relation to their commissioned tasks during the economic slowdown, or rather they are the effect of individual cost management and regional development policies performed by the LGs. In particular, this last issue - the size of undertaken investments by a given LG - may be a factor which to the largest extent influenced their current financial standing and ability to service existing debt as well as raise a new debt.

In this research the author employs the standard DEA method, originally developed by (Charnes et al. 1978). The method is widely described in the literature, so there is no need to present it in a detailed way. Below is just a short description based entirely on (Kucharski 2011). In the DEA method a best practice frontier is estimated based on the empirical data of inputs and outputs for the analyzed decision-making units (DMUs), in our case individual LGs. DMUs which are located on the frontier are efficient. For them, the efficiency measure $\theta$ is equal to 1 , where $\theta$ is a standardized measure from 0 to 1 . 
In general there are $n$ entities (DMUs). Each of them uses $P$ input categories in order to obtain $R$ specific outputs. The entity $h_{i}$ employs $x_{p i}$ of input $p$ and delivers $y_{r i}$ of output $r$. The inputs and outputs must be nonnegative with at least one input and one output greater than zero. The efficiency of each entity is calculated by solving $i$ following programming problems:

$$
\begin{gathered}
\theta_{i}=h_{i}(\mu, v)=\frac{\sum_{r=1}^{R} \mu_{r} y_{r i}}{\sum_{p=1}^{P} v_{p} x_{p i}} \rightarrow \max \\
\text { s.t. } \quad \frac{\sum_{r=1}^{R} \mu_{r} y_{r i}}{\sum_{p=1}^{P} v_{p} x_{p i}} \leq 1 \\
\mu_{r} \geq 0, v_{p} \geq 0
\end{gathered}
$$

where:

$h_{i}$ - efficiency of entity $i(i=1, \ldots, n)$

$\mu_{r}$ - weights assigned to respective outputs $(r=1, \ldots, R)$

$v_{p}$ - weights assigned to respective inputs $(p=1, \ldots, P)$.

The weight vectors $\mu$ and $v$ represent combinations of inputs and outputs for a given entity in the form of one 'virtual' input and one 'virtual' output so that a given entity was as close as possible to the best practice frontier. The vectors may be different for each DMU.

The above problem is transformed to a linear programming form by a Charnes-Cooper transformation:

$$
\begin{gathered}
g_{i}=\sum_{r=1}^{R} \mu_{r} y_{r i} \rightarrow \max \\
\text { s.t. } \quad \sum_{p=1}^{P} v_{p} x_{p i}=1 \\
\sum_{r=1}^{R} \mu_{r} y_{r i}-\sum_{p=1}^{P} v_{p} x_{p i} \leq 0 \\
\mu_{r} \geq 0, v_{p} \geq 0
\end{gathered}
$$

DEA can be a tool employed to measure changes of unsystematic risk. For each year it allows to identify a frontier of LGs with either strong debt 
service indicators along with an active development policy or with modest debt service indicators accompanied by a moderate investment need and operational surpluses. From a risk perspective both profiles are sound. From the perspective of this research, the particular advantage of the DEA method is that it does not impose a uniform distribution of $\theta$ in the range 0 to 1 for DMUs. For example, it is theoretically possible that all DMUs will be located on the frontier. Such a situation would indicate that there is no unsystematic risk.

Observations on the frontier, with $\theta=1$, are compared to observations with an inferior risk profile. For each LG, this distance to the frontier is equal to $1-\theta$ and represents an individual unsystematic risk measure (URM). The URM does not quantify unsystematic risk in absolute terms but allows to make comparisons between subcategories and/or individual LGs as well as assess changes between years. From a risk assessment perspective (e.g. in the credit process in a bank), this is a useful tool.

In this analysis, the following categories are used as inputs:

- investments per capita (two-year average); e.g. for 2008 this will be average investments for 2007-2008 divided by the population as of 31 December 2007. Investments are defined as $R b N D S, B 2$.

- operating revenues to operating expenses (net of interest payments) ratio. Definitions as in Section 3.

As outputs the following ratios are used:

- EBITDA / Gross Interest.

- FOCF / Net Debt. Definitions as in Section 4.

Due to the requirements of the DEA method, the data regarding the outputs needed some calibration, i.e. transforming negative values, adjusting outlayers, etc. First of all, observations for LGs without net debt (and as a result with a negative FOCF/ND ratio) were substituted with the maximum positive value of this ratio for other LGs. Secondly, observations for LGs with an operating deficit received minimum positive values. Thirdly, the LGs with very high EBITDA/GI and FOCF/ND ratios (the outliers) were downsized to 20 and 2.0, respectively. Proportional downsizing of the ratios was also done for the observations in the range of 10-20 and 1.05-2.0, respectively. ${ }^{3}$

The calculations were performed for three years: 2008 (the pre-crisis year in Poland), 2011 (the first year with the operational surplus statutory

\footnotetext{
${ }^{3}$ From a risk assessment perspective it is irrelevant whether in a given year the EBITDA/GI ratio was 50 or 500 . They both indicate an enormously strong capacity to service existing debt. However such outliers have an impact on DEA results and therefore require calibration.
} 
requirement) and 2013 (the last available year at the moment of conducting this research).

Additionally, the observations (i.e. interest expenses) from 2013 were adjusted to 2011 interest rate levels ceteris paribus (results denoted as '2013adj'). ${ }^{4}$ Interest rates are a systematic factor, so adjusting 2013 for 2011's interest rates will not change the risk ranking between individual LGs. However, it will reflect the comparable (though hypothetically) risk level from 2011's perspective, since after adjustment certain LGs may fall with their individual debt indicators below acceptable levels, indicating a potential growth of their risk.

Table 4

Unsystematic risk measure (URM) for LGs subcategories - selected statistics

\begin{tabular}{|c|c|c|c|c|}
\hline & 2008 & 2011 & 2013 & 2013adj \\
\hline \multicolumn{5}{|l|}{ TWCR: } \\
\hline average URM & 0.43 & 0.73 & 0.60 & 0.66 \\
\hline coefficient of variation & $63.2 \%$ & $30.8 \%$ & $47.2 \%$ & $41.6 \%$ \\
\hline \multicolumn{5}{|l|}{ Counties: } \\
\hline average URM & 0.44 & 0.60 & 0.58 & 0.62 \\
\hline coefficient of variation & $76.2 \%$ & $50.4 \%$ & $49.0 \%$ & $47.3 \%$ \\
\hline \multicolumn{5}{|l|}{ MB: } \\
\hline average URM & 0.44 & 0.73 & 0.67 & 0.71 \\
\hline coefficient of variation & $59.9 \%$ & $31.9 \%$ & $32.5 \%$ & $30.9 \%$ \\
\hline \multicolumn{5}{|l|}{ MRB: } \\
\hline average URM & 0.39 & 0.70 & 0.63 & 0.69 \\
\hline coefficient of variation & $71.4 \%$ & $34.0 \%$ & $36.5 \%$ & $34.4 \%$ \\
\hline \multicolumn{5}{|l|}{ RB: } \\
\hline average URM & 0.37 & 0.61 & 0.53 & 0.59 \\
\hline coefficient of variation & $62.3 \%$ & $47.1 \%$ & $48.2 \%$ & $45.4 \%$ \\
\hline \multicolumn{5}{|l|}{ Provinces: } \\
\hline average URM & 0.22 & 0.48 & 0.45 & 0.55 \\
\hline coefficient of variation & $85.4 \%$ & $59.7 \%$ & $42.8 \%$ & $37.4 \%$ \\
\hline
\end{tabular}

Source: own calculations with Efficiency Measurement System ver. 1.3.0 software.

\footnotetext{
${ }^{4}$ Average WIBOR 1M in 2011 amounted to $4.37 \%$ compared to $3.04 \%$ in 2013 , which had a direct impact on EBITDTA/Gross Interest indicators. Note that there is no adjustment of interest rates for 2008 in this analysis. In 2008, average WIBOR $1 \mathrm{M}$ amounted to $6.10 \%$, so the adjusted risk profile for 2008 observations would be even better than the actual ones compared to 2011 and 2013. Since risk profiles without adjustments for 2008 are clearly superior to other years in every category, adjusting interest rates for 2008 would deliver the same conclusions and therefore was skipped.
} 
The DEA calculations were performed with the following approach: input oriented, constant returns to scale, distance radial, convex structure. The results are presented in Table 4, Figure 1 and Appendix 1. A control calculation was also conducted of a similar model but with an additional input: 'operating revenues per capita (two-year average)'. It delivered almost identical results with some differences only for 2008, which were negligible for the general conclusions. The results of these calculations are available on request.

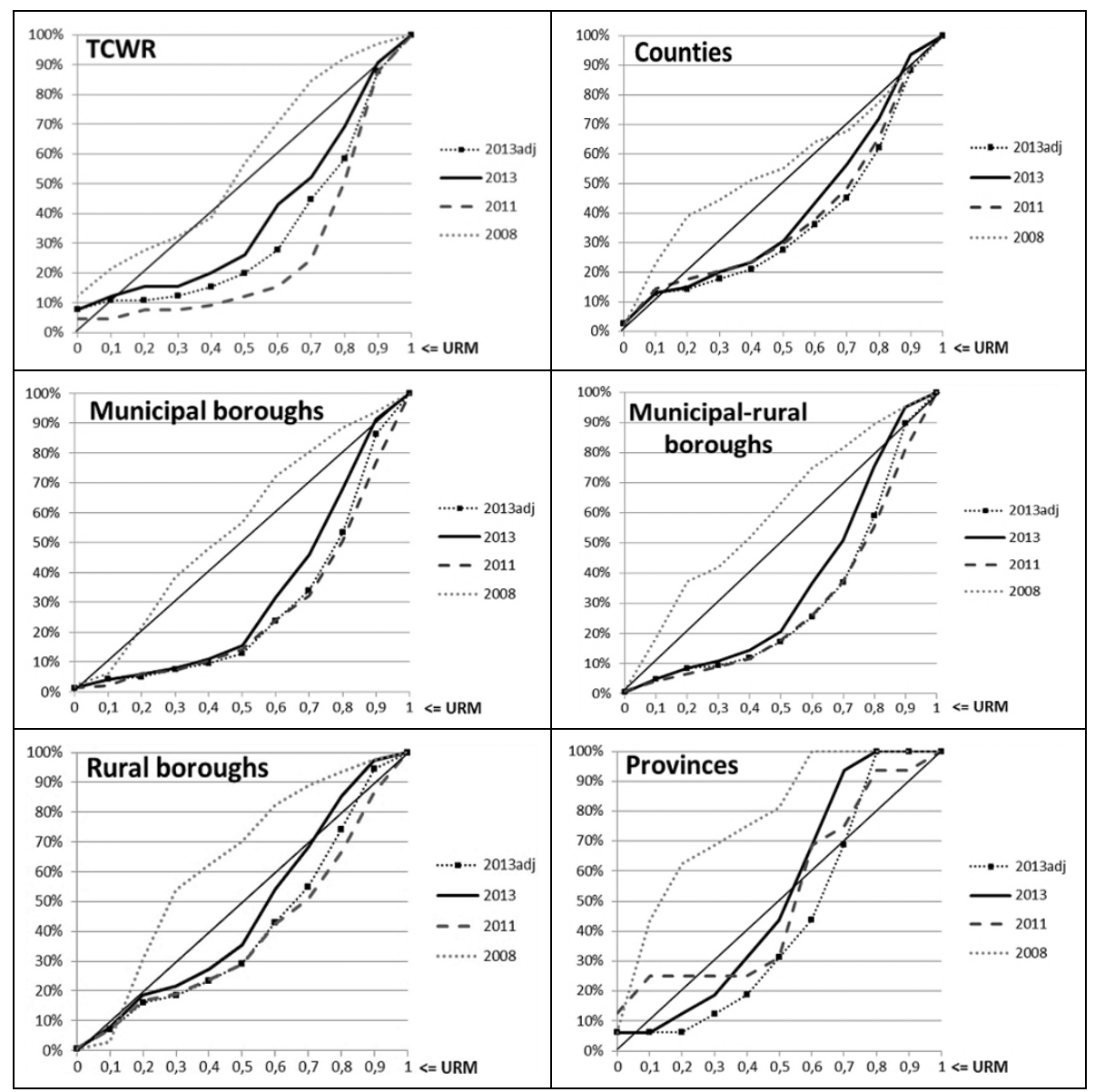

Note: The larger convexity of the distribution function indicates that there are more LGs with high unsystematic risk

Figure 1. Distributions of unsystematic risk measure (URM) for LGs' subcategories in 2008-2013

Source: own calculations with Efficiency Measurement System ver. 1.3.0 software. 
The distributions presented in Figure 1 and Appendix 1 are all statistically different from each other (see Table 5 for goodness of fit tests results).

Table 5

Results of goodness of fit tests $\left(\chi^{2}\right)$ between URM distributions

\begin{tabular}{l|c|c|c}
\hline & $\begin{array}{c}\text { Test statistics } \\
\chi^{2}\end{array}$ & $\begin{array}{c}\text { Degrees } \\
\text { of freedom }\end{array}$ & $\begin{array}{c}\text { Critical value } \\
(\mathrm{p})\end{array}$ \\
\hline Comparison of URM distributions for a specific LG subcategory between years: \\
\hline TWCR & 69.9 & 30 & 0.000 \\
\hline MB & 270.3 & 30 & 0.000 \\
\hline MRB & 629.3 & 30 & 0.000 \\
\hline RB & 1639.1 & 30 & 0.000 \\
\hline Counties & 167.4 & 30 & 0.000 \\
\hline \multicolumn{1}{c|}{ Comparison of URM distributions for all LG subcategories in a given year: } \\
\hline 2008 & 589.9 & 40 & 0.000 \\
\hline 2011 & 196.2 & 40 & 0.000 \\
\hline 2013 & 231.5 & 40 & 0.000 \\
\hline 2013 adj & 216.5 & 40 & 0.000 \\
\hline
\end{tabular}

Note: Tests for provinces were not run due to insufficient number of observations for this variable.

Source: own calculations.

The analysis generally confirmed that since the beginning of the economic slowdown there was a large increase of unsystematic risk in all LG categories. It is striking how significantly the group of LGs with a relatively high risk profile has grown since 2008, taking into account their revenue-cost position and investment activities. In 2013 there was some improvement in LGs' risk profile compared to 2011, however that was mainly due to a drop in market interest rates. Detailed research devoted to the sustainability of the LG sector debt under various scenarios of interest rate increases is presented in (Kluza 2016).

The analysis of LG subcategories delivered several vital observations. Firstly, in the case of the counties it showed that this category has relatively low unsystematic risk measures despite overall high risk. This is further evidence that this LG category is experiencing deep systemic problems, which may lead to solvency problems and structural changes resulting in the elimination of this category. Additionally, despite the low URM, this category has the highest coefficient of variation (CV), which correctly reflects the large diversity among individual counties. Counties with the highest unsystematic risk are usually owners of local hospitals. In the case of 
the ten counties with the highest URM, five of them still own hospitals, and four used to own one in the past and privatized it.

The municipal boroughs make the category with the highest unsystematic risk in the period 2011-2013, with an average URM of 0.71 in 2013adj. They are followed by municipal-rural boroughs with a URM of 0.69 (see also Appendix 1). In addition, these categories have the lowest coefficients of variation, e.g. $31 \%$ and $34 \%$ in 2013 adj respectively, which reaffirms the high unsystematic risk profile for the whole category. Almost $15 \%$ of municipal boroughs have a URM above 0.9. Examples of municipal boroughs with the highest URM are Piła, Rejowiec Fabryczny, SkarżyskoKamienna and Świeradów Zdrój, and for municipal-rural boroughs: Biały Bór, Kamień Pomorski, Nowy Staw, Pełczyce, Pisz, Przemków.

Additionally, MBs and MRBs are more vulnerable than other LG categories to potential interest rate increases (except for Provinces, but they are a relatively low risk category). Any relative improvement of their risk profile since 2011 was basically only due to lower market interest rates.

Towns with county rights are the category with the highest risk level among all LGs. Their URM of 0.66 indicates that in their case this is a relatively balanced mix of both systematic and unsystematic risk components. This result confirms intuition, because TWCR perform both the functions of the counties (high systematic risk) and municipal boroughs (high unsystematic risk). There is also a significant differentiation of results between individual TWCR with $\mathrm{CV}=42 \%$. This finding also confirms intuition because, for example, the largest TWCR has a population of 1.7 million and the smallest a population of 38,000, and as a result they perform partially different tasks for their inhabitants. However, there is no correlation between the value of URM and the population size of TWCR (the Pearson coefficient is around 0.1).

According to the model, the TWCR with the highest URM in 2013 were Bytom, Elbląg, Gdynia, Przemyśl, Siedlce, Sopot, Świętochłowice, and Swinoujście. Since 2011 the most remarkable upgrades of their financial position among TWCR with high URM were recorded by Jelenia Góra and Gorzów Wielkopolski.

In the case of difficulties, some TWCR may pose a significant threat to the financial sector. For example, in 2013 the debt of Gdynia amounted to PLN 556 million (USD 185 million) and in Elbląg PLN 301 million (USD 100 million). These values do not include the debt of dependent municipal companies. The average debt of TWCR amounted to PLN 470 million (USD 156 million) in 2013, without including the debt of 
municipal companies and health sector entities, so individual risk exposures for the financial sector are large.

A positive picture is presented by the rural boroughs. RBs, which have an overall favourable risk profile, did not accumulate unsystematic risk either. With their large diversification, this is currently the safest LG category. However, there is a high variance of results in this category $(\mathrm{CV}=45 \%)$, with around $6 \%$ of RBs with a very high URM (above 0.9 ). Riskier RBs are dispersed around the country with a relatively larger concentration in the Zachodniopomorskie and Podkarpackie provinces (e.g. Harasiuki, Kobylanka, Krzywca, Ostrowice, Rewal). In addition, one has to remember that the poorer RBs are reliant on compensatory subsidies from the central budget. In the case of central budget problems, the algorithm of such subsidies may be changed, which will harm the non-affluent RBs the most.

\section{CONCLUSIONS}

The financial and economic crises, which originated in 2007 in the United States, had a negative impact on the financial condition of local governments across the European Union. In Poland there was a rapid growth of indebtedness of the local government sector in 2008-2013. The debt grew from $2.3 \%$ to $4.2 \%$ of GDP. That was a result of systematic factors such as the slowdown of LGs' revenue growth combined with the increased amount of commissioned tasks carried out by LGs as well as the output of individual policies of each LG regarding cost management and the implementation of environmental and infrastructural projects.

This paper presented research devoted to changes in the local government credit risk profile in Poland. Risk assessment was conducted with financial ratios based on free operating cash flow and net debt as an alternative to the statutory debt limits defined in the Public Finance Law. Although the statutory limits are widely used in the assessment of the LGs' financial standing, they have serious flaws which may lead to misleading conclusions. For example, they do not take into account debt associated with EU co-financed projects on the one hand, and the cash position of LGs on the other. Moreover, in operational surplus they include proceeds from the sale of assets.

Next, the analysis of changes in the unsystematic risk of local government subcategories was conducted for 2008-2013. The analysis was performed with the use of the Data Envelopment Analysis method.

The study finds that the general risk profile of local governments strongly deteriorated compared to the pre-crisis year of 2008. Since 2011 it has 
improved slightly. However, this partial improvement was mainly due to a drop in market interest rates in 2013. Adjusting data for this factor reveals that the financial standing would not have changed in a positive way. The safest local government category in Poland are rural boroughs. In addition, they do not pose a concentration risk for financing institutions.

Two local government subcategories have relatively inferior risk profiles. The first one is the towns with county rights. This category consists of only 66 entities, but represents one third of Poland's population and 36\% of LG sector revenues. The towns with county rights have the highest debt levels $(\mathrm{ND} / \mathrm{R}=40.2 \%$ in 2013$)$ and noticeably weak debt service capacities (FOCF $/ \mathrm{ND}=21 \%$ in 2013). Additionally, some of them accumulated high unsystematic risk. As a result, around $20 \%$ of them have debt service indicators in warning areas.

The second category are the counties. Despite relatively low debt levels there is high systematic risk of this group. Without system reform of the counties, approximately $25 \%$ of them may have problems with performing the tasks commissioned to them or servicing their debt in the medium term. Moreover, both the counties and towns with county rights face contingent liabilities as they are also owners of public hospitals and are obliged to maintain their financial solvency.

The highest unsystematic risk occurs in the subcategory of municipal boroughs. This group is also the most vulnerable to potential increases in market interest rates. The positive observation is that their risk profile relatively improved in 2013 compared to 2011.

The current financial standing of LGs in Poland means that they will have difficulty maintaining the historical extent of their investments and regional development programmes. Some of them will also face problems with the full absorption of the EU funds available from the 2014-2020 Financial Perspective. Such problems will mostly affect the counties, towns with county rights and a large group of municipal boroughs. A lasting solution of this issue requires changes in the revenue sources of LGs, in particular increasing financing from the central budget, adequately to the commissioned tasks.

\section{REFERENCES}

Abad, P., Robles, M. D., Credit Rating Agencies and Unsystematic Risk: Is There a Linkage? Universidad Complutense de Madrid, Facultad de Ciencias Económicas y Empresariales, No. 2012-17, 2012. 
Barrell, R., Holland, D., Hurst, I., Fiscal Consolidation: Part 2. Fiscal Multipliers and Fiscal Consolidations, "OECD Economics Department Working Papers", OECD Publishing, No. 933, 2012.

Bisias, D., Flood, M., Lo, A., Valavanis, S., A Survey of Systemic Risk Analytics, Office of Financial Research. US Department of the Treasury, Working Paper \#0001, 2012.

Blöchliger, H., Decentralisation and Economic Growth - Part 1: How Fiscal Federalism Affects Long-Term Development, OECD Working Papers on Fiscal Federalism, OECD Publishing, No. 14, 2013.

Blöchliger, H., Égert, B., Decentralisation and Economic Growth - Part 2: The Impact on Economic Activity, Productivity and Investment, OECD Working Papers on Fiscal Federalism, OECD Publishing, No. 15, 2013.

Brunnermeier, M., Oehmke, M., Bubbles, Financial Crises, and Systemic Risk, NBER Working Paper No. 18398, September 2012.

Charnes, A., Cooper, W. W., Rhodes, E., Measuring the Efficiency of Decision Making Units, "European Journal of Operational Research", No. 2, 1978.

Cooper, L., Seiford, M., Zhu, J. (eds.), Handbook on Data Envelopment Analysis. Springer, 2011.

Crouhy, M., Galai, D., Mark, R., Risk Management [chapter: Credit Rating Systems]. McGraw Hill Professional, 2000.

Czudec, A., Kata, R., Metodyczne aspekty oceny gospodarki finansowej jednostek samorzadu terytorialnego [Methodical Aspects of Financial Standing Assessment of Local Governments], "Finanse Komunalne" [Municipal Finances], No. 10, 2012.

Donald, B., Glasmeier, A., Gray, M., Lobao, L., Austerity in the City: Economic Crisis and Urban Service Decline?, "Cambridge Journal of Regions, Economy and Society", No. 7, 2014.

Eggertsson, B., Krugman, P., Debt, Deleveraging and the Liquidity Trap: A Fisher-MinskyKoo Approach, “The Quarterly Journal of Economics”, pp. 1469-1513, 2012.

FITCH, International Local and Regional Governments Rating Criteria, FITCH Ratings, August 2012.

FITCH, Województwo Wielkopolskie. Raport kredytowy [Wielkopolskie Province. Credit Report]. FITCH Ratings, July 2013.

FITCH, Rating of Public-Sector Entities, FITCH Ratings, March 2014.

Fredriksen, K., Decentralisation and Economic Growth - Part 3: Decentralisation, Infrastructure Investment and Educational Performance, "OECD Working Papers on Fiscal Federalism", OECD Publishing, No. 16, 2013.

Haan, J. de, Klomp, J., Conditional Political Budget Cycles: A Review of Recent Evidence, "Public Choice", No. 157, 2013.

Hilscher, J., Wilson, M., Credit Ratings and Credit Risk: Is One Measure Enough?, AFA 2013 San Diego Meetings Paper, March 7, 2013.

Jajuga, K. (ed.), Zarzadzanie ryzykiem [Risk management]. PWN, Warszawa, 2009.

Kluka, L., Kluza K., Symulacja wptywu zmian ustawowych na dostepność finansowania dla JST. Nowe formy finansowania zadan samorzadowych [Simulation of the Impact of the Legal Changes on the Availability of Financial Resources for Local Governments. The 
New Forms of Financing Municipal Tasks.], "Finanse Komunalne" [Municipal Finances], No. 1-2, 2012.

Kluza, K., Wpływ zmian w ustawie o finansach publicznych na koszt finansowania samorzadów [Impact of Changes in the Public Finance Law on the Cost of Financing for Local Governments]. Zarządzanie i Finanse [Management and Finance], Vol. 11, No. 2, part 3, 2013.

Kluza, K., Efektywność polskich jednostek samorząu terytorialnego na tle samorzadów w Unii Europejskiej - weryfikacja adekwatności dochodów [Efficiency of Polish Local Governments in Comparison with Local Governments in the EU Countries. Analysis of Revenue Adequacy in the Polish Local Government Sector], "Finanse Komunalne" [Municipal Finances], No. 12, pp. 15-24, 2014.

Kluza, K., Sustainability of Local Government Sector Debt. Evidence from Monte-Carlo Simulations, "Lex Localis - Journal of Local Self-Government", Vol. 14, No. 1, pp. 115-132, January 2016.

KRRIO, Sprawozdania z działalności RIO i wykonania budżetu przez jednostki samorzadu terytorialnego w $2012 r$. [Activity Reports of Regional Comptroller Offices and Information on Budget Execution of Local Governments in 2012], Krajowa Rada Regionalnych Izb Obrachunkowych [National Council of Regional Comptroller Offices], Warszawa, 2012.

KRRIO, Sprawozdania z działalności RIO $i$ wykonania budżetu przez jednostki samorzadu terytorialnego w $2013 r$. [Activity reports of Regional Comptroller Offices and information on budget execution of local governments in 2013], Krajowa Rada Regionalnych Izb Obrachunkowych [National Council of Regional Comptroller Offices], Warszawa, 2013.

Kucharski, A., Metoda DEA w ocenie efektywności gospodarczej [DEA Method in the Assessment of Economic Efficiency], Katedra Badań Operacyjnych, Uniwersytet Łódzki [University of Lodz], 2011.

Łękawa, Z., Ocena efektywności gmin województwa dolnośląskiego z wykorzystaniem metody DEA [Assessment of Efficiency of Boroughs in Dolnoslaskie Province Using the DEA Method], Annales Universitatis Mariae Curie-Skłodowska, Lublin, Vol. XLVI, No. 4, 2012.

Marchewka-Bartkowiak, K., Wiśniewski, M., Indywidualny wskaźnik zadtużenia JST - ocena krytyczna i propozycje zmian [Individual Debt Ratio for Local Governments - Critical Assessment and Proposals of Changes, "Analizy" [Analyses], Biuro Analiz Sejmowych [Bureau of Parliament Analyses], no. 21 (88), 2012.

OECD, Consolidating Public Finances [in:] OECD Economic Surveys: Denmark 2012, OECD Publishing, 2012.

OECD, Local Public Finances and Municipal Reform [in:] OECD Economic Surveys: Finland 2014, OECD Publishing, 2014.

Palepu, K., Healy, P., Bernard, V., Business Analysis and Valuation: Using Financial Statements, Text and Cases [chapters: Financial Analysis and Credit Analysis and Distress Prediction], 3rd Edition, 2004.

Peck, J., Pushing Austerity: State Failure, Municipal Bankruptcy and the Crises of Fiscal Federalism in the USA, "Cambridge Journal of Regions, Economy and Society", No. 7, 2014.

Peterson, G., Measuring Local Government Credit Risk and Improving Creditworthiness, Prepared for World Bank, March 1998. 
S\&P, U.S. Local Governments General Obligation Ratings: Methodology and Assumptions, Standard \& Poor's Ratings Services, September 2013.

S\&P, Aktualizacja raportu: Rating miasta Łodzi podtrzymany na poziomie BBB+ [Report Update: Rating of the City of Lodz Maintained at BBB+Level], Standard \& Poor's Ratings Services, April 2014a.

S\&P, Methodology for Rating Non-U.S. Local And Regional Governments, Standard \& Poor's Ratings Services, June 2014b.

Sutherland, D., Hoeller, P., Merola, R., Fiscal Consolidation: How Much, How Fast and by What Means?, OECD Economic Policy Papers, No. 1, 2012.

Ustawa z dnia 27 sierpnia 2009 r. o finansach publicznych [Public Finance Law, 27 August 2009], Dziennik Ustaw 2009, No. 157, pos. 1240 as amended.

Vammalle, C., Hulbert, C., Sub-national Finances and Fiscal Consolidation: Walking on Thin Ice, OECD Regional Development Working Papers, OECD, 2013/02.

Veiga, L., Veiga, F., Intergovernmental Fiscal Transfers as Pork Barrel, "Public Choice", Vol. 155, 2013.

Zioło, M., Efficiency Assessment of Capital Expenditures of the Municipalities Using the DEA Method, Zeszyty Naukowe Uniwersytetu Szczecińskiego [Scientific Papers of Szczecin University], No. 727, 2012.

ZMP, Obywatelski projekt ustawy o zmianie ustawy o dochodach jednostek samorzadu terytorialnego [Civic Proposal of the Law Amending the Law on Local Government Revenues], materiały z XXXIII Zjazdu Związku Miast Polskich [documents from the 33rd Congress of The Association of Polish Cities], 9 March 2012. 


\section{APPENDIX 1}

Distributions of unsystematic risk measure (URM) in 2008-2013 for LG subcategories

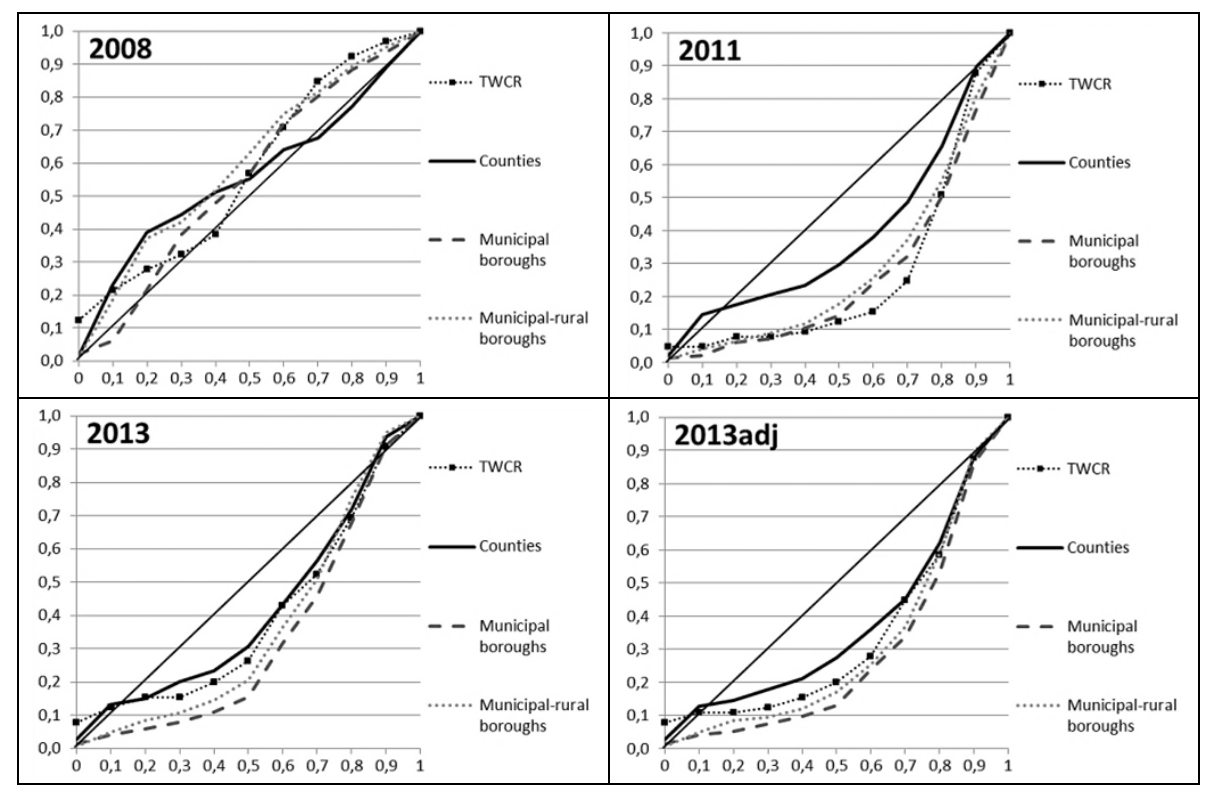

Note: for clarity, the charts depict only four LG categories which have an overall riskier profile.

Source: own calculations. 